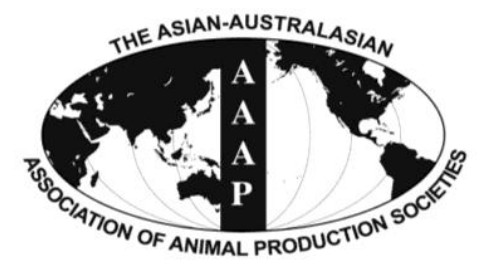

Asian Australas. J. Anim. Sci.

Vol. 26, No. 12 : 1726-1731 December 2013

http://dx.doi.org/10.5713/ajas.2013.13241

www.ajas.info

pISSN 1011-2367 elSSN 1976-5517

\title{
Effects of Dietary Electrolyte Balance on Growth Performance, Nitrogen Metabolism and Some Blood Biochemical Parameters of Growing Rabbits
}

\author{
J. W. Li, X. P. Wang, C. Y. Wang, Y. L. Zhu, and F. C. Li* \\ College of Animal Science and Technology, Shandong Agricultural University, Tai'an, 271018, China
}

\begin{abstract}
The effects of different dietary electrolyte balance (DEB) on growth performance, nitrogen (N) metabolism and some blood biochemical parameters were investigated in 2 to 3 months old growing rabbits. A total of 150 growing rabbits of 2 months age were randomly divided into five groups according to average body weight, with 30 rabbits in each group. The DEB levels of the five experimental diets were $-154,-3.16,+201,+347$, and $+500 \mathrm{meq} / \mathrm{kg}$ of dry matter $(\mathrm{DM})$, respectively. There was a $7-\mathrm{d}$ adaptation period and a 23-d experimental period. The results showed that the DEB levels had a quadratic affect on the average daily feed intake (ADFI) $(\mathrm{p}<0.001)$. The greatest ADFI was achieved when the DEB level was $+201 \mathrm{meq} / \mathrm{kg}$ DM. Fecal N (FN) content linearly decreased (0.047), while digestible $\mathrm{N}(\mathrm{DN})$, retained $\mathrm{N}(\mathrm{RN})$, efficiency of intake $\mathrm{N}$ converted into digestible $\mathrm{N}$ (DN/IN) and the efficiency of intake $\mathrm{N}$ converted into retained $\mathrm{N}$ (RN/IN) linearly increased with the DEB increase $(0.020,0.004,0.021$, and 0.049 , respectively). Serum phosphorus $(P)$ ion content linearly increased with the DEB increase $(p=0.036)$. The DEB had a quadratic relationship with serum anion gap $(\mathrm{AG})(\mathrm{p}=0.002)$ and serum parathyroid hormone $(\mathrm{PTH})$ content $(\mathrm{p}=0.016)$. The DEB levels quadratically affected base excess $(\mathrm{BE})$ in the plasma $(\mathrm{p}<0.001)$. In conclusion, the DEB unaffected growth performance but affected feed intake, $\mathrm{N}$ metabolism and some blood biochemical parameters of growing rabbits. (Key Words: Dietary Electrolyte Balance, Growing Rabbit, Growth Performance, Nitrogen Metabolism, Blood Biochemical Parameters)
\end{abstract}

\section{INTRODUCTION}

Mineral requirements of rabbits has been recently reviewed (Mateos et al., 2010), but there was limited information on some macroelements of the diet. It is well known that the relationship between $\mathrm{Na}^{+}, \mathrm{K}^{+}$, and $\mathrm{Cl}^{-}$(the dietary electrolyte balance, DEB) affects animal performance. The relationship between DEB and growth or production in poultry, swine and cows had been studied extensively (Melliere and Forbes, 1966; Madubuike, 1980; Mongin, 1981; Yen et al., 1981; Hu et al., 2007; Oba et al., 2011). Much less was known about the effect of the DEB on the reproductive response of does and bucks and there are few data on the zootechnical performance or acid-base status of growing rabbits (Chiericato and Rizzi, 2003). Chiericato and Rizzi (2004) found that increasing the DEB of breeding rabbit diets from 270 to $350 \mathrm{meq} / \mathrm{kg}$ tended to increase the mortality rate of does at farrowing, but did not

\footnotetext{
* Corresponding Author: Fuchang Li. Tel: +86-0538-82492228319, Fax: +86-0538-8241419, E-mail: chlf@ sdau.edu.cn Submitted May 1, 2013; Accepted Jul. 5, 2013; Revised Aug. 16, 2013
}

affect milk production or feed intake up to 21 days of lactation. Similarly, Rizzi et al. (2005) did not observe any effect on the performance of bucks during three reproductive cycles with electrolyte balances of 270 or 350 $\mathrm{meq} / \mathrm{kg}$ diets. No information on variation of this balance on the productivity of growing rabbits was available. The physiological status and feeding strategies of rabbits are different from those of poultry, swine and cows. Therefore, the present study was planned to examine the effect of varying levels of the DEB on the growth performance, nitrogen $(\mathrm{N})$ metabolism and some blood biochemical parameters of growing rabbits.

\section{MATERIALS AND METHODS}

\section{Animals and diets}

A total of 150 2-month-old growing rabbits (male: female ratio 1:1) with average body weight of $1,656 \pm 120 \mathrm{~g}$ were used in this study. All rabbits were randomly divided into five groups, 30 in each group (15 males and 15 females), and were fed with different experimental diets. 
The diets were formulated according to the requirement of growing rabbits recommended by NRC (1977) and de Blas and Mateos (2010). The DEB was the difference between milliequivalents of certain cations $(\mathrm{Na}, \mathrm{K})$ and anion $(\mathrm{Cl})$ in the complete feed and was calculated with the following equation (Mongin, 1981; Austic and Clevert, 1981): $\mathrm{DEB}=\mathrm{Na}+\mathrm{K}-\mathrm{Cl} \mathrm{meq} / \mathrm{kg}$ DM. Five diets were formulated to have $-154,-3.16,+201,+347$, and +500 $\mathrm{meq} / \mathrm{kg}$ DM of DEB, respectively (Table 1). The DEB levels were attained by using $\mathrm{NaHCO}_{3}$ and $\mathrm{CaCl}_{2}$. The feed was pelletized into $4 \mathrm{~mm}$ diameter. The rabbits were housed in individual cages $(60 \times 40 \times 40 \mathrm{~cm})$ and had free access to drinking water. During the trial, the rabbits were housed in a closed and ventilated building in which the maximum temperature was $15^{\circ} \mathrm{C}$, the minimum temperature was $5^{\circ} \mathrm{C}$ and the relative humidity ranged from $50 \%$ to $60 \%$. A cycle of $12 \mathrm{~h}$ of light and $12 \mathrm{~h}$ of dark was used throughout the trial.

\section{Experimental procedures}

The trial lasted 30 days with a $7-d$ adaptation and a $23-d$ experimental period including a 3 -d (the last 3 days) successive collection of feces, urine and blood samples. At the end of the trial, 40 rabbits ( 8 rabbits per group, 4 males and 4 females, and the average body weight of the 8 rabbits equaled to the average body weight of entire treatment group) were selected for the determination of $\mathrm{N}$ metabolism and blood plasma or serum parameters. The feed was offered ad libitum and refilled at 8:30 and 17:30 daily, meanwhile the residual feed was collected from the feeder. Feces, urine and residual feed were collected in the metabolism cages. Feces were collected separately each day, then weighed and mixed thoroughly. A portion of about 250 $\mathrm{g}$ feces samples put into plastic bottle and stored at $-20^{\circ} \mathrm{C}$. Fecal samples were dried at $60^{\circ} \mathrm{C}$ and ground to pass a 1 $\mathrm{mm}$ screen before further analysis. Urine was collected separately into plastic barrel and acidified with $20 \mathrm{~mL} / \mathrm{L}$ (v/v) $\mathrm{H}_{2} \mathrm{SO}_{4}(95 \%)$. After weighing and stirring the urine collected daily, a portion of about $150 \mathrm{~mL}$ urine was sampled into a plastic bottle and stored at $-20^{\circ} \mathrm{C}$.

All rabbits were weighed at the beginning ( $\mathrm{d} 60)$ and at the end (d 90) of the experimental period. The average daily weight gain (ADG) and average daily feed intake (ADFI) were recorded and the feed to gain $(\mathrm{F} / \mathrm{G})$ ratio was calculated.

Two arterial blood samples were taken from the central

Table 1. Ingredients and chemical composition of the experimental diets

\begin{tabular}{|c|c|c|c|c|c|}
\hline \multirow{2}{*}{ Items } & \multicolumn{5}{|c|}{$\mathrm{DEB}^{\mathrm{a}}(\mathrm{meq} / \mathrm{kg}$ of DM) } \\
\hline & -154 & -3.16 & +201 & +347 & +500 \\
\hline \multicolumn{6}{|l|}{ Ingredient (g/kg diet) } \\
\hline Maize & 250 & 250 & 230 & 250 & 240 \\
\hline Soybean meal & 170 & 170 & 160 & 170 & 170 \\
\hline Wheat bran & 150 & 150 & 180 & 150 & 170 \\
\hline Peanut vine & 380.5 & 388.9 & 400 & 387.5 & 364.9 \\
\hline $\mathrm{CaHPO}_{4}$ & 15 & 15 & 15 & 15 & 15 \\
\hline Salt & 5 & 5 & 5 & 5 & 5 \\
\hline Premix $^{\mathrm{b}}$ & 10 & 10 & 10 & 10 & 10 \\
\hline $\mathrm{NaHCO}_{3}$ & - & - & - & 12.5 & 25.1 \\
\hline $\mathrm{CaCl}_{2}$ & 19.5 & 11.1 & - & - & - \\
\hline Total & 1,000 & 1,000 & 1,000 & 1,000 & 1,000 \\
\hline \multicolumn{6}{|l|}{ Chemical composition } \\
\hline Digestible energy $(\mathrm{MJ} / \mathrm{kg})^{\mathrm{c}}$ & 10.46 & 10.46 & 10.46 & 10.46 & 10.46 \\
\hline Crude protein $(\mathrm{N} \times 6.25)^{\mathrm{c}}$ & 158 & 158 & 158 & 158 & 158 \\
\hline Crude fiber $(\%)^{\mathrm{c}}$ & 13.59 & 13.59 & 13.59 & 13.59 & 13.59 \\
\hline Ether extract $(\%)^{\mathrm{c}}$ & 3.00 & 3.00 & 3.00 & 3.00 & 3.00 \\
\hline Methionine+cysteine $(\%)^{\mathrm{c}}$ & 0.45 & 0.45 & 0.45 & 0.45 & 0.45 \\
\hline Lysine $(\%)^{\mathrm{c}}$ & 0.45 & 0.45 & 0.45 & 0.45 & 0.45 \\
\hline $\mathrm{Na}(\%)^{\mathrm{d}}$ & 0.24 & 0.24 & 0.24 & 0.58 & 0.94 \\
\hline $\mathrm{K}(\%)^{\mathrm{d}}$ & 0.93 & 0.94 & 0.95 & 0.94 & 0.95 \\
\hline $\mathrm{Cl}(\%)^{\mathrm{d}}$ & 1.76 & 1.22 & 0.52 & 0.52 & 0.54 \\
\hline DEB (meq/kg DM) & -154 & -3.16 & +201 & +347 & +500 \\
\hline
\end{tabular}

${ }^{a} \mathrm{DEB}=$ Dietary electrolyte balance; Analyzed values according to the milliequivalents of $\mathrm{Na}, \mathrm{K}$ and $\mathrm{Cl}$ in the whole feed and calculated with the following equation: $\mathrm{DEB}=\mathrm{Na}+\mathrm{K}-\mathrm{Cl} \mathrm{meq} / \mathrm{kg} \mathrm{DM}$.

${ }^{\mathrm{b}}$ The following premix ingredients were added to each kg of diet: Vitamin A, 8,000 IU; Vitamin $\mathrm{D}_{3,}, 1,000 \mathrm{IU}$; Vitamin E, $50 \mathrm{mg}$; Lys, $1.5 \mathrm{~g}$; Met, $1.5 \mathrm{~g}$; $\mathrm{Cu}, 50 \mathrm{mg} ; \mathrm{Fe}, 100 \mathrm{mg} ; \mathrm{Mn}, 30 \mathrm{mg} ; \mathrm{Mg}, 150 \mathrm{mg} ; \mathrm{I}, 0.1 \mathrm{mg}$.

${ }^{c}$ Calculated values according to the tables of feed composition and nutritive values in China (The 20th revised edition, 2009).

${ }^{\mathrm{d}}$ Analyzed values. 
Table 2. The effect of dietary electrolyte balance on the growth performance of experimental rabbits $(\mathrm{n}=30)$

\begin{tabular}{|c|c|c|c|c|c|c|c|c|}
\hline \multirow{2}{*}{ Items } & \multicolumn{5}{|c|}{$\mathrm{DEB}^{\mathrm{a}}$ (meq/kg of DM) } & \multirow{2}{*}{ R-MSE ${ }^{b}$} & \multicolumn{2}{|c|}{ p-value } \\
\hline & -154 & -3.16 & +201 & +347 & +500 & & Linear & Quadratic \\
\hline Average feed intake (g/d) & 105 & 105 & 111 & 106 & 108 & 3.3656 & $<0.001$ & $<0.001$ \\
\hline Average weight gain $(\mathrm{g} / \mathrm{d})$ & 20.62 & 23.99 & 24.74 & 23.19 & 24.59 & 5.1469 & 0.144 & 0.100 \\
\hline Feed to gain ratio $(\mathrm{g} / \mathrm{g})$ & 4.58 & 4.52 & 4.37 & 4.48 & 4.42 & 0.4761 & 0.394 & 0.619 \\
\hline
\end{tabular}

${ }^{\mathrm{a}}$ DEB $=$ Dietary electrolyte balance. ${ }^{\mathrm{b}} \mathrm{R}-\mathrm{MSE}=$ Root mean square error.

ear artery and collected at $16.00 \mathrm{~h}$ in the successive 3 sampling days at the end of the experimental period. About $5 \mathrm{~mL}$ of blood was collected into a heparinized tube. Plasma was extracted and the $\mathrm{pH}$ value, $\mathrm{HCO}_{3}^{-}$concentration, partial pressure of $\mathrm{CO}_{2}\left(\mathrm{pCO}_{2}\right)$ and $\mathrm{O}_{2}\left(\mathrm{pO}_{2}\right)$, total $\mathrm{CO}_{2}$ concentration and base excess (BE) were determined immediately. Another $10 \mathrm{~mL}$ of blood samples were kept in the dark at room temperature for $30 \mathrm{~min}$ and then centrifuged at $1,000 \times \mathrm{g}$ for $10 \mathrm{~min}$. The serum was placed into an Eppendorf tube and cryopreserved at $-20^{\circ} \mathrm{C}$ for later use.

\section{Chemical analyses}

Nitrogen $(\mathrm{N})$ contents of feed, faces and urine samples were determined by the Kjeldahl method (AOAC, 1990).

Contents of $\mathrm{Na}$ and $\mathrm{K}$ in feed samples were determined by atomic absorption spectrometry (361 CRT, Lengguang analytical instruments Co. Ltd., Nanjing, China) (Jackson et al., 1992). Contents of $\mathrm{Cl}$ in feed samples were determined via thiocyanate inverse titration (Cotlove et al., 1958).

The ion contents of $\mathrm{Na}, \mathrm{K}, \mathrm{Ca}, \mathrm{P}, \mathrm{Cl}$ and anion gap (AG) in the serum were determined by the electrolyte analyzer (XD-687, Shanghai Xunda Co. Ltd., Shanghai, China). Contents of amino acids in the serum were determined by Hitachi automatic amino acid analyzer (835-50, Tokyo, Japan). Parathyroid hormone (PTH), thyrocalcitonin (CT) and bone Gla-containing protein (BGP) contents in the serum were determined by a radioimmunoassay procedure (the tracer was 125I). Test kits were purchased from Tianjin Xiehe Hospital Biotech. Co. Ltd., and the $\gamma$ arithmometer (DFM-96) used was produced by Hefei Zhongcheng Electromechanical Technology Exploration Co. Ltd and validated according to the manufacturer's protocol using a rabbit-specific ELISA kit for PTH, CT, and BGP. All assays were performed in duplicate. The intra- and interassay CV were $6 \%$ and $10 \%$, respectively, for PTH analyses, $5 \%$ and $9 \%$, respectively, for CT and $9 \%$ and $11 \%$, respectively, for BGP.

The $\mathrm{pH}$ value, $\mathrm{HCO}_{3}{ }^{-}$concentration, partial pressure of $\mathrm{CO}_{2}\left(\mathrm{pCO}_{2}\right)$ and $\mathrm{O}_{2}\left(\mathrm{pO}_{2}\right)$, total $\mathrm{CO}_{2}$ concentration and $\mathrm{BE}$ in the plasma were determined by an automated blood gas analyzer (ABL5, Radiometer medical APS, Copenhagen, Demark).

\section{Statistical analysis}

Linear and quadratic effects of the DEB levels on all parameters were analyzed by SAS using the regression procedures (SAS, 1985). Root mean square error (RMSE) and coefficient of determination $\left(\mathrm{R}^{2}\right)$ were used to evaluate the goodness of fit for the different effects.

\section{RESULTS AND DISCUSSION}

\section{The effect of dietary electrolyte balance on growth performance}

Table 2 displays the effects of the DEB on growth performances. There was a quadratic effect of the DEB on the ADFI. The greatest ADFI $(p<0.001)$ occurred in the rabbits fed the diet of $+201 \mathrm{meq} / \mathrm{kg} \mathrm{DM}$ of DEB. In addition, there was no effect on F/G and ADG among the treatments $(\mathrm{p}>0.05)$.

As one of the important factors that influenced animal production performance, the DEB had a close relationship with animal growth performance. For normal growth and development and the best production performance, the diet must have an ideal electrolyte balance. In this study, the DEB varied from -154 to $+500 \mathrm{meq} / \mathrm{kg}$ DM and unaffected the $\mathrm{ADG}$ and $\mathrm{F} / \mathrm{G}$ of experimental rabbits. The ADG was lower (20-25 g/d) and F/G was higher (4.3 to 4.6), because we used crossbred rabbits from the mating of New Zealand white rabbits $\times$ local white rabbits and they were housed in a lower temperature.

\section{The effect of dietary electrolyte balance on nitrogen metabolism}

The effects of the DEB on $\mathrm{N}$ metabolism is shown in Table 3. The fecal $N(F N)$ linearly decreased $(p=0.047)$, while digestible $\mathrm{N}(\mathrm{DN})$, retained $\mathrm{N}(\mathrm{RN})$, the efficiency of intake $\mathrm{N}$ converted into digestible $\mathrm{N}$ (DN/IN) and the efficiency of intake $\mathrm{N}$ converted into retained $\mathrm{N}$ (RN/IN) linearly increased with the DEB increase $(p=0.020,0.004$, 0.021 , and 0.049 , respectively). In addition, no effect was observed on $\mathrm{N}$ intake (IN), urinary $\mathrm{N}$ (UN) and the efficiency of digestible $\mathrm{N}$ converted into retained $\mathrm{N}$ $(\mathrm{RN} / \mathrm{DN})$ among the treatments $(\mathrm{p}>0.05)$.

The DEB affects the utilization of nitrogen $(\mathrm{N})$ and other nutrients by influencing the cation-anion balance of the body. Haydon et al. (1990) indicated that urinary $\mathrm{N}$ 
Table 3. The effect of dietary electrolyte balance on the nitrogen metabolism of experimental rabbits $(\mathrm{n}=8)$

\begin{tabular}{|c|c|c|c|c|c|c|c|c|}
\hline \multirow{2}{*}{ Items } & \multicolumn{5}{|c|}{$\mathrm{DEB}^{\mathrm{a}}(\mathrm{meq} / \mathrm{kg}$ of DM) } & \multirow{2}{*}{ R-MSE } & \multicolumn{2}{|c|}{ p-value } \\
\hline & -154 & -3.16 & +201 & +347 & +500 & & Linear & Quadratic \\
\hline Intake $N(I N, g / d)$ & 3.76 & 3.74 & 3.84 & 3.75 & 3.81 & 0.0874 & 0.259 & 0.527 \\
\hline Fecal N (FN, g/d) & 1.22 & 1.19 & 1.14 & 1.01 & 1.02 & 0.1295 & 0.047 & 0.073 \\
\hline Urinary N (UN, g/d) & 1.01 & 0.99 & 0.88 & 0.91 & 0.75 & 0.2142 & 0.163 & 0.223 \\
\hline Digestible $N(D N, g / d)^{c}$ & 2.54 & 2.55 & 2.70 & 2.74 & 2.79 & 0.2741 & 0.020 & 0.061 \\
\hline Retained N (RN, g/d $)^{\mathrm{d}}$ & 1.53 & 1.56 & 1.82 & 1.83 & 2.04 & 0.1799 & 0.004 & 0.010 \\
\hline $\mathrm{DN} / \mathrm{IN}(\%)^{\mathrm{e}}$ & 67.55 & 68.18 & 70.31 & 73.07 & 73.23 & 4.9362 & 0.021 & 0.055 \\
\hline $\mathrm{RN} / \mathrm{IN}(\%)^{\mathrm{f}}$ & 40.69 & 41.71 & 47.40 & 48.80 & 53.54 & 8.8093 & 0.049 & 0.140 \\
\hline $\mathrm{RN} / \mathrm{DN}(\%)^{\mathrm{g}}$ & 60.24 & 61.18 & 67.41 & 66.79 & 73.12 & 9.7043 & 0.571 & 0.758 \\
\hline
\end{tabular}

${ }^{\mathrm{a}} \mathrm{DEB}=$ Dietary electrolyte balance. ${ }^{\mathrm{b}} \mathrm{R}-\mathrm{MSE}=$ Root mean square error. ${ }^{\mathrm{c}} \mathrm{DN}=\mathrm{IN}-\mathrm{FN} .{ }^{\mathrm{d}} \mathrm{RN}=\mathrm{IN}-\mathrm{FN}-\mathrm{UN}$.

${ }^{\mathrm{e}} \mathrm{DN} / \mathrm{IN}(\%)=$ The efficiency of intake $\mathrm{N}$ converted into digestible $\mathrm{N} .{ }^{\mathrm{f}} \mathrm{RN} / \mathrm{IN}(\%)=$ The efficiency of intake $\mathrm{N}$ converted into retained $\mathrm{N}$.

${ }^{\mathrm{g}} \mathrm{RN} / \mathrm{DN}(\%)=$ The efficiency of digestible $\mathrm{N}$ converted into digestible $\mathrm{N}$.

decreased and deposition efficiencies of intake $\mathrm{N}$ and digestible $\mathrm{N}$ of growing pigs increased with the increase of dietary DEB levels. In the present study, the fecal $\mathrm{N}$ linearly decreased, while the DN, DN/IN and RN/IN linearly increased with the DEB increase. So, the results of studies with different monogastric animals were similar.

The effect of dietary electrolyte balance on serum biochemical parameters

Table 4 displays the effects of the DEB on serum biochemical parameters measured in the present study. The serum $P$ ion concentration linearly increased with the DEB increase $(p=0.036)$. There was a quadratic effect of the DEB on the serum anion gap. The greatest serum anion gap $(p=0.002)$ was observed in the rabbits fed with the diet of $3.16 \mathrm{meq} / \mathrm{kg}$ DM. There was a quadratic effect of the DEB on serum PTH contents. The greatest serum PTH content ( $p$ $=0.016)$ was observed in the rabbits fed with the diet of
$+500 \mathrm{meq} / \mathrm{kg}$ DM. In addition, no effect was observed on the other measured serum biochemical parameters among the treatments ( $p>0.05)$. Among the serum electrolytes (Na, $\mathrm{K}, \mathrm{Cl}, \mathrm{Ca}, \mathrm{P}$ ) examined in the study, only the concentration of serum $\mathrm{P}$ changed significantly among treatments.

The PTH is a hormone that mobilizes Ca flow from bone stores and dietary sources into the blood while CT has a reverse effect. In the present study, a quadratic effect of the DEB on serum PTH contents occurred. BGP is a protein synthesized and secreted by osteoblast cells of the bones, and could be used as an indicator of the activity of bone mineral, mainly calcium metabolism. The difference of serum BGP among treatment was not significant in the present study. Because the difference of $\mathrm{Ca}$ metabolism between animals, the responses of blood PTH, CT and BGP concerned with $\mathrm{Ca}$ metabolism to the $\mathrm{DEB}$ or dietary cation-anion difference (DCAD) varied.

Table 4. The effect of the DEB on serum relative traits of experimental rabbits $(n=8)$

\begin{tabular}{|c|c|c|c|c|c|c|c|c|}
\hline \multirow{2}{*}{ Items } & \multicolumn{5}{|c|}{$\mathrm{DEB}^{\mathrm{a}}$ (meq/kg of DM) } & \multirow{2}{*}{ R-MSE ${ }^{b}$} & \multicolumn{2}{|c|}{ p-value } \\
\hline & -154 & -3.16 & +201 & +347 & +500 & & Linear & Quadratic \\
\hline$\overline{\mathrm{K}^{+}(\mathrm{mmol} / \mathrm{L})}$ & 5.12 & 4.93 & 4.73 & 5.00 & 5.16 & 0.3861 & 0.930 & 0.180 \\
\hline $\mathrm{Na}^{+}(\mathrm{mmol} / \mathrm{L})$ & 140 & 142 & 143 & 144 & 142 & 4.1194 & 0.273 & 0.158 \\
\hline $\mathrm{Cl}^{-}(\mathrm{mmol} / \mathrm{L})$ & 103 & 106 & 104 & 107 & 106 & 4.324 & 0.147 & 0.292 \\
\hline $\mathrm{Na}^{+}+\mathrm{K}^{+}-\mathrm{Cl}^{-}(\mathrm{mmol} / \mathrm{L})$ & 42.23 & 40.28 & 43.34 & 42.45 & 41.29 & 2.2090 & 0.884 & 0.725 \\
\hline $\mathrm{Ca}^{2+}(\mathrm{mmol} / \mathrm{L})$ & 3.63 & 3.53 & 3.55 & 3.53 & 3.68 & 0.1348 & 0.662 & 0.051 \\
\hline $\mathrm{P}^{5+}(\mathrm{mmol} / \mathrm{L})$ & 2.99 & 2.86 & 3.04 & 3.19 & 3.16 & 0.2704 & 0.036 & 0.103 \\
\hline Anion gap (mmol/L) & 21.09 & 22.58 & 18.89 & 18.14 & 20.25 & 1.8976 & 0.415 & 0.002 \\
\hline Methionine (mg/L) & 8.13 & 7.69 & 12.21 & 9.14 & 9.12 & 2.3477 & 0.602 & 0.206 \\
\hline Lysine (mg/L) & 31.72 & 32.18 & 33.86 & 32.77 & 33.64 & 6.5034 & 0.726 & 0.891 \\
\hline Arginine $(\mathrm{mg} / \mathrm{L})$ & 10.84 & 8.44 & 9.72 & 10.07 & 9.12 & 5.8488 & 0.789 & 0.954 \\
\hline Total amino acids (mg/L) & 472 & 475 & 514 & 510 & 486 & 98.9466 & 0.987 & 0.755 \\
\hline PTH $(n g / L)^{c}$ & 201 & 131 & 121 & 134 & 260 & 99.1068 & 0.482 & 0.016 \\
\hline $\mathrm{CT}(\mathrm{pg} / \mathrm{mL})^{\mathrm{d}}$ & 125 & 122 & 104 & 91.14 & 81.82 & 53.0103 & 0.427 & 0.734 \\
\hline $\operatorname{BGP}(\mathrm{ng} / \mathrm{mL})^{\mathrm{e}}$ & 212 & 216 & 240 & 252 & 212 & 65.0754 & 0.568 & 0.209 \\
\hline
\end{tabular}

${ }^{\mathrm{a}} \mathrm{DEB}=$ Dietary electrolyte balance. ${ }^{\mathrm{b}} \mathrm{R}-\mathrm{MSE}=$ Root mean square error.

${ }^{\mathrm{c}} \mathrm{PTH}=$ Parathyriod hormone. ${ }^{\mathrm{d}} \mathrm{CT}=$ Thyrcalcitonin. ${ }^{\mathrm{e}} \mathrm{BGP}=$ Bone Gla-containing protein. 
Table 5. The effect of the DEB on plasma acid-base status of experimental rabbits $(n=8)$

\begin{tabular}{|c|c|c|c|c|c|c|c|c|}
\hline \multirow{2}{*}{ Items } & \multicolumn{5}{|c|}{$\mathrm{DEB}^{\mathrm{a}}$ (meq/kg of DM) } & \multirow{2}{*}{ R-MSE ${ }^{b}$} & \multicolumn{2}{|c|}{$\mathrm{p}$-value } \\
\hline & -154 & -3.16 & +201 & +347 & +500 & & Linear & Quadratic \\
\hline pH value & 7.30 & 7.32 & 7.36 & 7.34 & 7.32 & 0.0324 & 0.262 & 0.057 \\
\hline $\mathrm{pCO}_{2}(\mathrm{Kpa})^{\mathrm{c}}$ & 4.85 & 4.9 & 4.86 & 4.54 & 4.78 & 0.6974 & 0.539 & 0.828 \\
\hline $\mathrm{pO}_{2}(\mathrm{Kpa})^{\mathrm{d}}$ & 11.40 & 11.38 & 12.67 & 12.03 & 11.49 & 1.2353 & 0.114 & 0.211 \\
\hline $\begin{array}{l}\mathrm{HCO}_{3}^{-} \text {concentration } \\
(\mathrm{mmol} / \mathrm{L})\end{array}$ & 18.25 & 18.38 & 18.86 & 17.43 & 18.13 & 2.6902 & 0.589 & 0.866 \\
\hline $\begin{array}{l}\text { Total } \mathrm{CO}_{2} \text { concentration } \\
(\mathrm{mmol} / \mathrm{L})\end{array}$ & 19.51 & 19.00 & 20.29 & 20.14 & 19.71 & 2.6059 & 0.862 & 0.908 \\
\hline Base excess (mmol/L) & -2.25 & -1.72 & 1.83 & 1.75 & 1.85 & 1.2557 & $<0.001$ & $<0.001$ \\
\hline
\end{tabular}

${ }^{\mathrm{a}} \mathrm{DEB}=$ Dietary electrolyte balance. ${ }^{\mathrm{b}} \mathrm{R}-\mathrm{MSE}=$ Root mean square error.

${ }^{\mathrm{c}} \mathrm{PCO}_{2}=$ Partial pressure of $\mathrm{CO}_{2} \cdot{ }^{\mathrm{d}} \mathrm{PO}_{2}=$ Partial pressure of $\mathrm{O}_{2}$.

\section{The effect of dietary electrolyte balance on plasma acid- base status}

The effects of DEB on plasma acid-base status is shown in Table 5. It was found that the DEB quadratically affected $\mathrm{BE}$ in the plasma $(\mathrm{p}<0.001)$. The greatest plasma BE were observed in the rabbits fed with the diet of $+500 \mathrm{meq} / \mathrm{kg}$ DM. In addition, no effect was observed on the other measured plasma acid-base status parameters among the treatments $(\mathrm{p}>0.05)$.

In the present study, the DEB levels affected BE in the plasma and unaffected the $\mathrm{pH}$ value, $\mathrm{HCO}_{3}{ }^{-}$concentration, $\mathrm{pCO}_{2}, \mathrm{pO}_{2}$ and total $\mathrm{CO}_{2}$ concentration in the plasma of the experiment rabbits. Patience et al. (1987) illustrated that the acid-base balance of growing pigs was affected by dietary electrolyte balance. Haydon et al. (1990) used 96 crossbred growing-finishing pigs to determine the effect of DEB on blood gases and found that blood $\mathrm{pH}, \mathrm{HCO}_{3}$, total $\mathrm{CO}_{2}$ and $\mathrm{BE}$ excess increased linearly as dietary $\mathrm{EB}$ increased.

In conclusion, the DEB did not affect growth performance but affected feed intake, $\mathrm{N}$ metabolism and some blood biochemical parameters of growing rabbits.

\section{ACKNOWLEDGEMENTS}

This study was supported by the earmarked fund for Modern Agro-industry Technology Research System (CARS-44-B-1) and the Special Fund for Agro-scientific Research in the Public Interest (200903006).

\section{REFERENCES}

AOAC. 1990. Official methods of analysis. 15th edn. Association of Official Analytical Chemists, Arlington, Virginia.

Austic, R. E. and C. C. Calvert. 1981. Nutritional interrelationships of electrolytes and amino acids. Fed. Proc. 40:63-67.

Chiericato, G. M. and C. Rizzi. 2003. Effect of the dietary electrolyte balance on the reproductive response of rabbit does. Ital. J. Anim. Sci. 2 (Suppl. 1):477-479.

Chiericato, G. M. and C. Rizzi. 2004. Study of the effect of the dietary mineral content on the reproductive performance of rabbits of both sexes and on the zootechnical performance of their litters. Riv. Coniglicoltura, 41:44-48.

Cotlove. E. H., H. V. Trantham and R. L. Bowman. 1958. An instrument and method for automatic, rapid, accurate, and sensitive titration of chloride in biological samples. J. Lab. Clin. Med. 51:461-468.

de Blas, C. and G. G. Mateos. 2010. Feed formulation. In: Nutrition of the Rabbit (Ed. C. de Blas and J. Wiseman, $2^{\text {nd }}$ Ed.). CABI Publishing, Wallingford, UK, pp. 241-253.

Haydon, K. D., J. W. West, and M. N. McCarter. 1990. Effect of dietary electrolyte balance on performance and blood parameter of growing-finishing swine fed in high ambient temperatures. J. Anim. Sci. 68:2400-2406.

Hu, W. P. K. Jr. Limin and M. R. Murphy. 2007. Relationships between dry matter intake and acid-base status of lactating dairy cows as manipulated by dietary cation-anion difference. Anim. Feed Sci. Technol. 136:216-225.

Jackson, J. A., D. M. Hopkins, Z. Xin, and R. W. Hemken. 1992. Influence of cation-anion balance on feed intake, body weight gain and humoral response of dairy calves. J. Dairy Sci. 75: 1281-1286.

Madubuike, F. N. 1980. Nutritional interrelationships of minerals and basic amino acids in growing pigs. Ph.D. Thesis. Cornell University, Ithaca, NY.

Mateos, G. G., P. G. Rebollar, and C. de Blas. 2010. Minerals, vitamins and additives. In: Nutrition of the Rabbit (Ed. C. de Blas and J. Wiseman, 2nd Ed.). CABI Publishing, Wallingford, U. K., pp. 128-129.

Melliere, A. L. and R. M. Forbes. 1966. Effect of altering the dietary cation-anion ratio on food consumption and growth of young chicks. J. Nutr. 90:310-314.

Mongin, P. 1981. Recent advances in dietary anion-cation balance: applications in poultry. Proc. Nutr. Soc. 40:285.

National Research Council. 1977. Nutrient requirements of rabbits. 2th Ed. National Academy Press, Washington, DC.

Oba, M., A. E. Oakley, and G. F. Tremblay. 2011. Dietary Ca concentration to minimize the risk of hypocalcaemia in dairy cows is affected by the dietary cation-anion difference. Anim. Feed Sci. Technol. 164:147-153.

Patience, J. F., R. E. Austic, and R. D. Boyd. 1987. Effect of dietary electrolyte balance on growth and acid-base status in swine. J. Anim. Sci. 64:457-466. 
Rizzi, C. G. Brecchii and G. M. Chiericato. 2005. A study on the reproductive performance and physiological response of rabbit bucks red on diets with two different mineral contents. In: Proceedings of the 8th World Rabbit Congress (Ed. C. M. Becerril and A. Pro), Puebla, Mexico, pp. 336-342.
SAS Institute Inc. 1985. Users Guide: Basics. SAS Institute, Cary, North Carolina, USA.

Yen, J. T., W. G. Pond, and R. L. Prior. 1981. Calcium chloride as a regulator of feed intake and weight gain in pigs. J. Anim. Sci. 52:778-782. 